\title{
Sociolinguistic Functions of Igbo Language: Implications for Education and Mass Communication
}

\author{
Afoma R.Okudo \\ Email: afomao@rocketmail.com;afomaak@gmail.com; \\ aokudo@unilag.edu.ng; +2348025201690 \\ Department of Arts and Social Sciences Education, \\ Faculty of Education, University of Lagos, Lagos State, Nigeria. \\ Ifeagwazi, Patricia A.(Mrs) \\ Email: ebonypatif@gmail.com; +2348037447953 \\ Department of Igbo \& other Nigerian Languages, \\ Nwafor Orizu College of Education \\ Nsugbe, Anambra State, Nigeria.
}

\section{Doi:10.5901/mjss.2013.v4n11p28}

\section{Abstract}

This paper aims to investigate whether the plausibility of Igbo language being neglected and will soon suffer attrition is a reality or not. It takes a close look at some language functions which the lgbo language is able to perform over a stipulated period of time. The theoretical framework of ethnolinguistic vitality forms the basis of this study. This study used descriptive design and questionnaire was the instrument used for data collection. The population of the study comprised three (3) Colleges of Education in the South East Educational Zone of Nigeria that offer courses for the acquisition of both Nigerian Certificate in Education (NCE) and Bachelor in Education (B.Ed), and six (6) radio stations were randomly selected; those that broadcast Igbo programmes from six (6) states in Nigeria viz: Abia, Anambra, Delta, Enugu, Imo and Lagos. Data collected were analyzed based on the language functionalities of education and mass communication. The analysis reveals that lgbo language still has strong ethnolinguistic vitality and a great chance of survival since it still serves as a veritable tool of communication in many sociolinguistic contexts such as educational school subjects and mass communication. The paper concludes by stating that Igbo language is not greatly endangered as some people think, and that the outcry that the Igbo language will soon go extinct is just an overstatement. However, the paper goes on to suggest some ways of concretizing and promoting lgbo language so as to prevent it from suffering extinction.

Keywords: Igbo language, ethnolinguistic vitality, language functionalities

\section{Introduction}

Language is primarily a tool to be used, to uphold and protect the reason for the core existence of certain group of people. It has a complex nature. Language is the strongest of all the unconscious agreements which hold a society together (Gleason, 1969). Linguistics is a scientific study of language. Language is a purely human and non-instinctive method of communicating ideas, emotions and desires by means of a system of voluntarily produced symbol. It is a system of arbitrary vocal symbols used by human communication by means of which a social group co-operators.

Sociolinguistics is the study of language in relation to the society. It is also a relative newcomer to the linguistic fold. According to Tiwale(2011),sociolinguistics is more interested in real speech, within and among communities. Their overriding concern is with the way in which language varies according to the social context in which it used and the social group to which it belongs. The social variables that influence speech include personal factors such as age and education, as well as more general ones like nationality, race and gender.

Evidently, speech which is the fastest means of communication is an aspect of language. Speech is not only a social activity but also a social property owned by the society and the speech community of any speaker. It is in this line of thought that Yule (2004) averts that speech is a form of social identity and is used, consciously or unconsciously, to indicate membership of different social groups or different speech communities.

For language to serve its primary function of communication and for it to be preserved, it must be spoken by its 
owners lest it will be endangered. Every language existed first as a spoken language before being committed to writing. Even today, some languages of the world are serving their owners but they have not been committed to writing because they have no orthography. Such languages are still valued and safeguarded by their owners such that they are still viable. On the contrary, some languages have lost some or all their speakers and are greatly endangered. Agbedo (2004) posits that the number of languages in the world is shrinking. Out of the roughly 6,909 languages now spoken, up to half are already endangered or on the brink of extinction. Agbedo further notes that, it is being estimated that globally some 4,000 languages have already been lost, with some 6,000 remaining but with the majority facing one level of risk or the other. In Nigeria, Lewis (2009: 78) observes that in all, the country has a total of 527 languages, 514 living languages, 2 second languages without mother tongue speakers, 11 with no known speakers.

According to Amfani (2010), language loss is always attributed to a domineering influence of a particular language on the dying language, and this accusation often turns into several social crises. He further forecasts that without a strong national policy on Nigerian languages, the languages will continue to decay and eventually die, and one day, every Nigerian will loose his or her linguistic identity since language is accepted to be the people's identity.

Over the years, there has been an outcry that Igbo language is fast dying and will soon suffer extinct. The outcry has made many people believe that the Igbo language is the most neglected of the three major Nigerian languages (Hausa, Igbo and Yoruba).

This study therefore sets out to investigate the level of this plausibility especially in the areas of mass communication and educational system.

\section{Theoretical Framework}

This study is anchored on the framework of Ethnolinguistic Vitality (EV). Vitality as a concept is found in a variety of contexts, each of which offers different insights. Ethnolinguistic Vitality according to Giles and Bourhis (1994) is that which makes a group likely to behave as a distinctive, active and collective entity within the intergroup setting.

Fishman (1989) opines that interaction network that employs the language for one or more vital language functions is an important indicator of ethnolingiustic vitality. The more speakers of a language variety are, the higher their status and the greater the groups' language vitality, the greater the chance for linguistic survival. Stewart (1968) asserts that for language to have a given function, it should serve at least minimally, as a vehicle of communication in a specific sociolinguistic context. He goes further to list the language functions which included: official, provincial, language of wider communication, international, capital city, group, educational, school subjects, literacy and religious. To Stewart's list Edward (1994) added many other functions such as work, speech acts and events.

According to Johnson, Giles and Bourhis (1983), the more vitality an ethnolinguistic group enjoys, the more it will be able to use its own language so as to survive and thrive as a collective entity. They outlined three dimensions of socio-structural variables which influence the vitality of ethno-linguistic groups to include demographic, institutional support and status. Demographic variables are those related to the absolute number of speakers and their distribution through the national, regional, or urban territory. Institutional support consists of the recognition accorded the group either in the use of the language in terms of research, educational policies and the use of the language in both the print and the electronic media.Status factor refers to a community's social prestige in its language and culture.

Language endangerment according to Agbedo (2011) is a serious problem; he posits that endangered languages are languages that are threatened by extinction because they are not passed on to younger generations. He further avers that an endangered language is not used in formal education and its communicative role is limited to in-group communication and with such traditional domains as rituals, festivals, and communal meetings.

Emenanjo (2010) asserts that all living phenomenon human beings, groups (tribal, ethnic or racial), plants, animals and languages become endangered when their original, natural, indigenous habitats, ecologies or environments become hostile, unfriendly, uncomfortable, in-conducive, or spent. This assertion shows that endangerment is not peculiar to languages but linguists are concerned with language endangerment. Thus, this study would look into the situation of Igbo language to know whether the outcry that Igbo language is endangered is true or not, taking the situations in the mass communication and educational system.

\section{Literature Review}

Emenanjo (2010) posited a research carried out in College of Education, Agbor, Delta State, Nigeria to know the people's level of attachment to their language. It was revealed that the people had obvious attachment or love for their language 
as it was depicted that $90 \%$ of the respondents wanted their mother tongue revived and modernized while $82 \%$ of the respondents were strongly against English displacing their mother tongue and thus becoming the only language available in their posterity.

Again, research carried out about Usen, a Yoruboid language spoken is the Ovia North East Local Government Area of Edo State in Nigeria revealed that Usen was indeed endangered due to the attitude of its speakers which was as a result of political and linguistic dominion as well as rural-urban migration. Some intervention strategies were outlined to help to rescue the Usen language from going into extinct, since it was not being taught in schools in the Usen Community.

Ohiri-Aniche (2007) studied some adults from four randomly selected states in Nigeria to know whether the Nigerians were aware of the phenomenon of language endangerment and especially that their own language could become extinct before the end of the century. Findings of that study revealed that most Nigerians were unaware of the phenomenon of language endangerment and especially about the possibility of their own language becoming extinct within a few generations. Most of them would not want their language to cease to exist. So there was room for right actions to be pursued to halt the present march of the country's indigenous languages towards death and ultimate extinction.

This study differs from the above empirical studies because it looked at language endangerment from the angle of language vitality with focus on the Igbo language based on the language functions of an important indication of ethnolinguistic vitality.

The scope of this study covered the language functions of the Igbo language in the areas of teachers teaching Igbo language, students studying the Igbo language, and radio stations broadcasting Igbo programmes.

\section{Research Methodology}

Descriptive survey design was used for this study. It covered teachers teaching Igbo language between the years 2008 to 2012 in a given College of Education; and radio stations that broadcast Igbo programmes.

\section{Population}

The population of this study comprised three (3) Colleges of Education in the South East Educational Zone that offer courses for the acquisition of both Nigerian Certificate in Education (NCE) and Bachelor in Education (B.Ed). There were 45 lecturers in the Department of Igbo and other Nigerian language. Six (6) states that broadcast Igbo programmes in the radio were randomly selected which include: Abia, Anambra, Enugu, Imo and Lagos form the population for this study. Out of the entire population, one (1) College of Education with 17 lecturers; and 3 radio stations were randomly selected.

\section{Instrumentation}

Questionnaire was used to elicit the necessary information (data) and respondents cooperated very well. The data collected were analyzed based on how they are able to satisfy the language functions outlined by Stewart (1968) and Edward (1994) viz: educational, school subjects, literacy radio etc. The ability of the data to satisfy or not to satisfy the above findings will help to determine the ethnologuistic vitality of the Igbo language and its status of endangerment.

\section{Data Presentation Analysis}

Here, data collected were analyzed and presented

Table I: Shows the three radio stations sampled and the number of Igbo programmes offered by each weekly.

\begin{tabular}{|l|c|}
\hline Name of Radio Station & No of Igbo Programme per week \\
\hline Bond FM 92.9, Radio Nigeria Ikoyi Lagos & 66 \\
\hline Anambra Broadcasting Services Radio 188.5FM Awka & 141 \\
\hline Radio Sapientia, 95.3FM Onitsha & 09 \\
\hline
\end{tabular}


One of the signs of language ethnolinguistic vitality is its ability to be used in radio and television broadcasting. For the purpose of radio broadcasting, three radio stations were sampled one national, one state and one privately owned.

Table I above shows that the national radio station in a non-Igbo speaking state offers sixty-six Igbo radio programmes per week. While the state radio station in an Igbo speaking area offers one hundred and forty one (141) Igbo programmes per week. On the other hand, the private radio station in an Igbo speaking area offers up to nine (9) Igbo programmes per week. This shows that radio broadcasting is one of the active functions which the lgbo language serves in the society. This implies that the Igbo language still has a strong ethnolinguistic vitality in the area of mass communication.

Table 2a: Staff Strength in Igbo Language Department

\begin{tabular}{|l|c|c|c|c|}
\hline & $\mathbf{2 0 0 8 / 2 0 0 9}$ & $\mathbf{2 0 0 9 / 2 0 1 0}$ & $\mathbf{2 0 / 1 0 / 2 0 1 1}$ & $\mathbf{2 0 1 1 / 2 0 1 2}$ \\
\hline Fulltime lecturers & 8 & 11 & 14 & 16 \\
\hline Part-time lecturer & 4 & 3 & 2 & 1 \\
\hline Total & 12 & 14 & 16 & 17 \\
\hline
\end{tabular}

Table 2 above shows the staff strength of Igbo language teachers in the Department of Igbo and other Nigerian languages of Nwafor Orizu College of Education, Nsugbe (NOCEN) Anambra State from 2008 to 2012. It revealed that the number of fulltime lecturers is on the increase while that of the part-time lecturers is declining within the stipulated period under review.

Table 2b: NCE students' enrolment in the Department of Igbo and other Nigerian languages.

\begin{tabular}{|c|c|c|c|}
\hline $\mathbf{2 0 0 8 / 2 0 0 9}$ & $\mathbf{2 0 0 9 / 2 0 1 0}$ & $\mathbf{2 0 1 0 / 2 0 1}$ & $\mathbf{2 0 1 1 / 2 0 1 2}$ \\
\hline 275 & 210 & 185 & 96 \\
\hline
\end{tabular}

Table 2c: B.Ed students' enrolment in the Department of Education/lgbo linguistic

\begin{tabular}{|l|c|c|c|c|}
\hline & $\mathbf{2 0 0 8 / 2 0 0 9}$ & $\mathbf{2 0 0 9 / 2 0 1 0}$ & $\mathbf{2 0 / 1 0 / 2 0 1 1}$ & $\mathbf{2 0 1 1 / 2 0 1 2}$ \\
\hline Direct Entry Student & 4 & 11 & 23 & 36 \\
\hline Sandwich Students & 13 & 22 & 31 & 35 \\
\hline UTME student & 6 & 14 & 25 & 31 \\
\hline Total & 23 & 47 & 79 & 102 \\
\hline
\end{tabular}

Table $2 b$ shows decrease in the number of students' enrolment for those pursuing NCE while table $2 c$ shows an increase in the number of students' enrolment for those pursuing first degree in the Department of Education/Linguistics in affiliation with the University of Nigeria, Nsukka. The simple explanation to this decrease and increase in the tables $2 a$ and $b$ above is that people want to acquire higher certificates. Thus, these tables confirm the educational function of the Igbo language as an aspect of ethno linguistics vitality. Language is said to serve educational function if it is used to educate people formally and informally or both. The above data revealed that lgbo language is still being used for communicative media and in education. Again, teachers teaching Igbo language and students studying Igbo language for the acquisition of higher certificate are on the increase as shown above in table $2 a$ above.

\section{Findings}

The findings of this study show that Igbo language is employed for many vital language functions such as education and mass communication. The speaking of Igbo language is encouraged by law and radio broadcasters through radio broadcasters. Students in tertiary institutions studying Igbo language are increasing yearly. These show that the Igbo language is enjoying strong ethnolinguistic vitality and has a great chance for survival in the face of other languages that encroach on it due to the various social functions it serves. Thus the outcry that Igbo language will soon suffer extinction is not a reality but an overstatement. 


\section{Recommendations}

However, recommendations are being made for proper preservation of Igbo language because prevention is better than cure:

1. Parents and guardians should be communicating with children/wards in their mother tongue/lgbo language in this context.

2. Policy makers and government should make sure that policy concerning mother tongue (Igbo language inclusive) is being implemented properly and the defaulters be brought to book.

3. Awareness should be created for the masses to know and understand the importance of safeguarding and promoting one's mother tongue which is the carrier of one's cultural heritage.

4. Investing in the research, text materials development of the Igbo language should be encouraged so that Igbo language would be in line with the globalization trend.

\section{Conclusion}

The finding of this study concerns with the revalorization of indigenous Nigerian languages strategy. This, according to Agbedo, Abata-Ahura and Edward (2012) postulated that revalorization refers to the new ideology which brings fresh dimensions to the mother tongue schooling system whereby indigenous languages of ex-colonial states of Africa and Asia are given added impetus in terms of value. The essential objective has been to invest in local language with added value and by so doing guarantee their advantage and practical use in education and other official purposes. Thus, considering the various language function which the Igbo language performs as discussed in this study, it should be said that Igbo language has taken bold steps towards the revalorization strategy.

It also agrees with Salawu (2004), that the mass media that use indigenous languages are important for the purpose of information, mobilization and continuity (survival of the language and culture).

Again, the findings of this study was also supported by Salawu (2006) that radio stations across Nigeria actually contributed to the promotion of a number of the nation's languages through various message types and programmes, chit- chats, and musical programmes.

\section{References}

Agbedo, C.U. (2011). Problems of Multilingual Nations: The Nigerian Perspective. Nsukka: ACE Resources Consult.

Agbedo, C.U. Abatu-Abura, L.I. Krisagbedo, E.C., \& Edward, C. (2012). Mother tongue and Pedagogic disability of the Nigerian School Child. A case for revalorization of indigenous Nigerian languages. Journal of Education and Practice.New York:UK @iiste.org pp45-55.

Amfani, A.H. (2001). "Language \& Literary and the Challenges of Socio-Economic Crises in Nigeria" Keynote address presented at the Maiden national Conference on Linguistics, language and literature in Nigeria Nsukka 20 - 23 July.

Cooper, R. (1989). Language Planning and Social Change. Cambridge: Cambridge University Press.

Edwards J. (1985). Language, Society and Identity. Oxford Blackwill.

Edwards, J. (1994). Multilingualism London Routledge.

Emenanjo, E.N. (1990). Multilingualism, Minority languages and Language Policy in Nigeria. Agbor Central Books Ltd. (2010). Endangered Languages in Nigeria. Port Harcourt. M \& J Grand Orbit Communications Ltd.

Fishman, J. (1989). Language and ethnicity in minority sociolinguistic perspective. Clevedon Multilingual Matters.

Gile, H. \& Johnson, P. (1981). "The Role of Language in ethnic group relations" In J.C. Turnner \& H. Giles (eds). Integroup behavior (pp 199-243), Oxford: Blackwell.

Giles, H. (ed) (1977). Language, ethnicity and intergroup Relation. London, Aeade Mic Press.

Gleason, H.A. (1969). An Introduction to descriptive Linguistics, Oxford Claredon Press.

Ohiri-Aniche, C. (2011), 6th Chief Dr. F.C. Ogbalu Memorial Lecture Onitsha: Varsity Publishing Company.

Salawu, A. (2004). The Yoruba and their language Newspapers: Origin, Nature, Problems and Prospect - Studies of Tribes and Tribals, Vol 2, No.2.

Salawu, A. (2006) (Ed). Indigenous Language Media on Africa. (BAAC) Iganmi - Lagos.

Stewart, W. (1968). "A Sociolinguistic typology for describing national Multilingualism.

K.J.A. Fishman (ed). Readings in the Sociology of Language Pp. 531 - 545. The Hargue:Mourton.

Tiwale,S.R.(2011).Impact of mother-tongue on communicative English. K.M. Agrawal College, Kalyan (W) Vol. 1, Issue . 1 / February 2011, pp. 41-43

Yule, G. (2004). The Study of Language. Cambridge, Cambridge University Press. 